\title{
The Lysogenicity of Staphylococci isolated in Poland
}

\author{
By B. KARSKA, W. KOZAK, B. NARBUTOWICZ AND A. STOLARSKA \\ Research Institute of Mother and Child, Warsaw, Poland
}

(Received 2 June 1960)

\begin{abstract}
SUMMARY
Strains of staphylococci were tested for lysogenicity and different 'lysogenicity patterns' were defined on the basis of the phage lytic spectra. The test of lysogenicity was used to indicate the pathogenicity, and to complement the phagetyping pattern. None of the coagulase-negative strains (65) carried a phage. The lysogenicity patterns of $76 \%$ of the coagulase-positive strains (122 tested) were determined. With the method of phage typing $80 \%$ of the coagulase-positive strains of staphylococci were classified. By using both methods (phage-typing and the test of lysogenicity) the classification of $92 \%$ of coagulase-positive strains was possible. Differentiation of identical phage-typing patterns was obtained by using lysogenicity patterns.
\end{abstract}

\section{INTRODUCTION}

It has been reported that there is an association between the prophage state of staphylococci and (i) coagulase production (Karska, 1958); (ii) resistance to antibiotics (Wahl \& Fouace, 1958); (iii) the phage-typing pattern (Smith, 1948; Lowbury \& Hood, 1953; Rountree, 1956; Wahl \& Fouace, 1958; Asheshov \& Rippon, 1959; Rountree, 1959). Moreover, the transduction of staphylococcal bacteriophage calls attention to gene transfers accomplished by staphylococcal bacteriophage (Morse, 1959). These observations suggest that the introduction of lysogenicity patterns to the classification of staphylococci may facilitate the differentiation of these strains.

\section{METHODS}

The strains of staphylococci used came from various sources; 171 were isolated from children hospitalized with various diseases in the Research Institute of Mother and Child in Warsaw during 1955 to 1959 , and 16 strains were isolated from members of the Institute staff. The pathogenicity of these strains were determined by the coagulase test. The coagulase-positive strains (122) were obtained from: swabs from throat or nose (60), swabs from ears (1), pus (31), urine (1), exudates from sinuses (7), puncture of pleura (13), bile (1), eye (1), blood culture (1), skin vesicles (1). The coagulase-negative strains (65) came from: swabs from throat or nose (55), swabs from ears (2), pus (4), urine (4), puncture of sinuses (1), eye (4), blood culture (1), swabs from vagina (2), tooth socket (2).

The twenty staphylococcal strains used to propagate the phages for routine phage typing were obtained from the National Collection of Type Cultures, Colindale, London, England. They are designated by the same number as the phages with the prefix PS. The phages obtained from Colindale were: $3 \mathrm{~A}, 3 \mathrm{~B}, 3 \mathrm{C}, 6,7,42 \mathrm{E}, 47,52$, 
54, 55, 70, 73, 75, 77. Those obtained from the National Staphylococcal Phages Centre, PZH, Warsaw, were: 29, 52 A, 53, 71, 79, 80*.

The strains of staphylococci were tested for: lysogenicity ('lysogenicity patterns'), coagulase production, phosphatase production, mannitol fermentation, pigment production, and phage-typing patterns according to Williams \& Rippon (1952) and Rippon (1956).

The strains of staphylococci were tested for lysogenicity as follows.

The organisms were grown in nutrient broth (brain heart infusion broth; Narbutowicz, 1955) at $37^{\circ}$ for $18 \mathrm{hr}$. Then $0.5 \mathrm{ml}$. of culture was flooded on the surface of an agar plate, dried and induced with ultraviolet (u.v.) radiation for 6 sec. at a distance of $42 \mathrm{~cm}$. from a Hanovia lamp type 10204. The plates, protected from light, were put into a refrigerator for $24 \mathrm{hr}$. Subsequently $2 \mathrm{ml}$. broth were added, removed and centrifuged at $3000 \mathrm{rev} . / \mathrm{min}$. for $30 \mathrm{~min}$. The supernatant fluids were tested by plating them on appropriate indicator strains. The results were read after $6-7 \mathrm{hr}$. at $37^{\circ}$ and subsequently after $12 \mathrm{hr}$. at room temperature.

The strains that were not shown to be carrying a phage were tested by the crossculture method (Fisk, 1942), induced by u.v. irradiation (Hewitt, 1952). As basal strains twenty propagating strains from Colindale and thirteen coagulase-positive indicator strains from our collection were used. The coagulase-negative strains were also tested with twenty-two coagulase-positive and 35 coagulase-negative indicator strains from our collection. The different sensitivity of basal strains to bactericidal activity of u.v. radiation made us use different times of irradiation. Thus the strains induced on basal strains PS $3 \mathrm{~A}, 3 \mathrm{~B}, 6,7,29,42 \mathrm{E}, 73$, and 80 were irradiated for 10 sec., while those induced on basal strains PS $3 \mathrm{C}, 42 \mathrm{D}, 47,52,55,70,71$ and 77 were irradiated only $3 \mathrm{sec}$. Whenever strains PS 53, 54, 75 were used as basal strains, they were grown on an agar plate at $37^{\circ}$ for $1 \mathrm{hr}$. Then the tested strains were plated on the basal strains, dried and induced by u.v. irradiation for 3 sec. In each case the distance from the lamp was $57 \mathrm{~cm}$. The strains induced on basal strains isolated in our department were irradiated for $6 \mathrm{sec}$. at distance of $42 \mathrm{~cm}$. from the lamp. After induction the agar plate was protected from light, and incubated at $37^{\circ}$ for 24. hr.

When it had been ascertained that the cultures were lysogenic, a square of agar was cut out of the area of confluent phage lysis and put into a test-tube with $2 \mathrm{ml}$. broth. The culture was shaken and put into an incubator for $4 \mathrm{hr}$. and then centrifuged for $30 \mathrm{~min}$. at $\mathbf{3 0 0 0} \mathrm{rev} . / \mathrm{min}$. The supernatant fluid was plated on the basal strain as well as on the tested one.

The 'lysogenicity patterns' were designated by the lytic spectrum of liberated phages on the standard set of propagating strains. For example, when a lysogenic strain had liberated phages able to propagate on PS 80, PS 79, PS 73, the 'lysogenicity pattern' was designated as PS 80/79/73.

Bacteriophages may be classified by their plaque morphology, resistance to physical and chemical agents, susceptibility to specific antisera and cross-resistance tests, but the host range has proved the most useful for diagnostic purposes because of its technical simplicity. According to Rippon (1956) the propagating strains of the typing phages are suitable for the determination of the lytic group of newly isolated phages. However, it is evident that many different phages may lyse the same propagating strain. 


\section{RESULTS}

No phage could be obtained from the 65 coagulase-negative strains. Induction was carried out three times on 20 propagating strains from Colindale and 70 strains from our collection. In contrast, 93 of the 122 coagulase-positive strains released phages. The analysis of the pathogenicity of these staphylococci gave the following results. Of the 65 coagulase-negative strains 2 produced phosphatase, 9 fermented mannitol, 9 produced golden pigment, 12 demonstrated phage-typing patterns. Of the 122 coagulase-positive strains 117 produced phosphatase, 121 fermented mannitol, 1 produced white pigment, 97 indicated phage-typing patterns. The results are summarized in Table 1.

Table 1. Characteristics of 187 staphylococcal strains isolated in Poland in the years 1955-59

Strains
Lysogenic
Produced phosphatase and fermented mannitol
Did not produce phosphatase but fermented mannitol
Produced phosphatase but did not ferment mannitol
White pigmented
Golden pigmented
Belonged to the phage group
I
II
III
I/II
I/II/III
II/III

Not typable with phages

$\begin{array}{cc}\begin{array}{c}65 \text { coagulase } \\ \text { negative } \\ \text { strains }\end{array} & \begin{array}{c}\text { 122 coagulase } \\ \text { positive } \\ \text { strains }\end{array} \\ 0 & 93 \\ 1 & 116 \\ 8 & 5 \\ 1 & 1 \\ 56 & 1 \\ 9 & 121 \\ & \\ 2 & 57 \\ 2 & 4 \\ 8 & 15 \\ 0 & 2 \\ 0 & 19 \\ 0 & 1 \\ 53 & 25\end{array}$

\section{Lysogenicity and phage typing of staphylococci}

In tests for phage-typing pattern on 109 strains the following results were obtained: 76 strains were typable with phages at their routine test dilution (RTD), and 33 strains were typable with phages in a concentration 1000 times stronger (1000 RTD). Coagulase-negative strains were for the most part resistant to the action of bacteriophages. Among the 65 investigated strains only 12 were able to synthesize these phages.

After investigation of 122 strains the phage pattern of 97 coagulase-positive strains was defined. The strains were able to synthesize from 1 to 8 various phages. The highest frequency of synthesizing activity was found with the following phages: phage 80 (54, strains), phage 54 (26 strains), phage 79 (22 strains). The phages 55, $29,42 \mathrm{E}$ were synthesized only in exceptional cases.

The 'lysogenicity pattern' has been established in 93 coagulase-positive strains of the 122 tested. Phages liberated from 82 strains were able to propagate on indicator strains from Colindale and those released from 11 strains were able to propagate only on indicator strains from our collection.

Phages liberated from lysogenic strains lysed from 1 to 6 various propagating strains. Most frequently lysed were PS 80 (phages liberated from 38 strains), 
PS 7 (phages from 33 strains), PS 73 (phages from 31 strains). Strains PS 52A, PS 29 and PS 6 were lysed only exceptionally. Strains PS 29, PS 52, PS 8 B, PS 55, PS 71 and PS $52 \mathrm{E}$ were never lysed by phages liberated from tested strains.

By means of the phage-typing method $80 \%$ of coagulase-positive strains of staphylococci were classified, and 76\% by means of the 'lysogenicity patterns'. The percentage of classified strains increases when both methods are used. It was found that 14 of the 25 untypable strains liberated phages and 17 of the 29 not lysogenic coagulase-positive strains were typable by means of bacteriophages. By using both these methods 112 strains (92\%) were classified. Strains of uniform phage patterns can be divided into smaller units. Such differentiation of strains with a uniform phage pattern 80 into subgroups with various 'lysogenicity patterns' is illustrated in Table 2.

Table 2. 'Lysogenicity patterns' of 38 coagulase-positive strains of staphylococci with phage pattern 80

$\begin{array}{ccc}\begin{array}{c}\text { Current } \\ \text { number }\end{array} & \text { 'Lysogenicity pattern' } & \begin{array}{c}\text { Number of } \\ \text { strains }\end{array} \\ 1 & \text { PS80 } & 11 \\ 2 & \mathrm{PS80} / 52 \mathrm{~A} / 7 & 1 \\ 3 & \mathrm{PS80} / 79 / 73 & 1 \\ 4 & \mathrm{PS80} / \mathbf{3 A} / \mathbf{7 3} & 1 \\ 5 & \mathrm{PS80} / 7 & 5 \\ 6 & \mathrm{PS80} / 73 & 12 \\ 7 & \mathrm{PS80} / 77 & 1 \\ 8 & \mathrm{PS3A} / 73 & 1 \\ 9 & \text { Lysogenic on indicator strains of our collection } & 3 \\ 10 & \text { Not lysogenic strains } & 2\end{array}$

\section{DISCUSSION}

The introduction of the 'lysogenicity pattern' into the classification of staphylococci may be of use for the definition of pathogenicity of the strain, and as a supplementary analysis of the phage-typing method. In agreement with Karska (1958) there exists a relationship between the presence of the prophage in the bacterial cell and the coagulase production. This statement is based on the lack of ability, in our tests, to liberate bacteriophages in $100 \%$ of 65 coagulase-negative strains, and the ability to liberate bacteriophages in $76 \%$ of coagulase-positive strains (122 tested). Evidence was found that the larger the number of indicator strains the more probable was the determination of lysogenicity of coagulasepositive staphylococcal strains. The 'lysogenicity test' presents an additional criterion for the determination of the pathogenicity of staphylococcal strains and in doubtful cases this test may be used to supplement the methods applied hitherto. The parallel investigation of the 'lysogenicity pattern' and of the phage-typing pattern increase the number of classified strains and enable the division of uniform lytic groups into smaller subgroups. This division is an important factor for the investigations of epidemics and for the origin and course of outbreaks of infection due to staphylococci, because it allows the detection of differences among otherwise apparently identical strains.

Supported by grants of the Polish Academy of Sciences VI Department. Our sincere thanks are due to the National Collection of Type Cultures, Colindale, 
London, and to the Polish Centre of Staphylococcal Phages, Warsaw, for providing bacteriophages and propagating strains. We wish to thank Mrs K. Wilczynska for her very competent technical assistance.

\section{REFERENCES}

Asheshov, E. H. \& Ripron, J. E. (1959). Changes in typing pattern of phage-type 80 staphylococci. J. gen. Microbiol. $20,634$.

FIsk, R. T. (1942). Studies on staphylococci. I. Occurrence of bacteriophage carriers among strains of Staphylococcus aureus. J. infect. Dis. 71, 153.

HewrtT, L. F. (1952). Diphtheria bacteriophages and their relation to the development of bacterial variants. J. gen. Microbiol. 7, 362 .

Karska, B. (1958). Zmienność wirulencji gronkoweów pod wpływem fagów. Zesz. Probl. Nauki Polsk. 16, 155.

Lowbury, E. J. I. \& Hood, A. M. (1953). The acquired resistance of Staphylococcus aureus to bacteriophage. J. gen. Microbiol. 9, 524.

Morse, M. L. (1959). Transduction by staphylococcal bacteriophage. Proc. nat. Acad. Sci., Wash. 45, 722.

NARButowicz, B. (1955). Badania nad zmiennościa jadotwórczości maczugowców błonicy pod wpływem fagów. Acta microbiol. Polon. 4, 245.

Rippon, J. E. (1956). The classification of bacteriophages lysing staphylococci. J. Hyg., Camb. 54, 123.

Rountree, P. M. (1956). Variations in related series of staphylococcal bacteriophages. J. gen. Microbiol. 15, 266.

Rountree, P. M. (1959). Changes in the phage-typing patterns of staphylococci following lysogenization. J. gen. Microbiol. 20, 620.

SмIтн, H. W. (1948). Investigations on the typing of staphylococci by means of bacteriophage. II. The significance of lysogenic strains in staphylococcal type designation. J. Hyg., Camb. 46, 82.

Wahl, R. \& Fouace, J. (1958). Modifications des 'types' de staphylocoques par perte de prophage ou par lysogénisation. Zbt. Bakt. (Orig.), 171, 573.

WILliAms, R. E. O. \& RipPon, J. E. (1952). Bacteriophage typing of Staphylococcus aureus. J. Hyg., Camb. 50, 320. 